\title{
The Culture in Ocumare Del Tuy: Rebuilding a Reality (Footnote 1)
}

\author{
Jennifer Zapata ${ }^{1 *}$ and Carlos Agelvis ${ }^{2}$ \\ ${ }^{1}$ Sociologist Magna cum Laude of the Universidad Central de Venezuela, Magister in Social Comunicación Social, Venezuela \\ ${ }^{2}$ Sociologist, Educator in social sciences of the Universidad central de Venezuela, Venezuela
}

Submission: August 10, 2019; Published: August 27, 2019

*Corresponding author: Jennifer Zapata, Sociologist Magna cum Laude of the Universidad Central de Venezuela, Magister in Social Comunicación Social, Venezuela

Abstract

This article is an approach to the characteristic's aspects of the culture in Ocumare del Tuy, town locate in the Miranda state in Venezuela. Where the hybrid culture is present, that is stay in the social relationships until these days.

\section{Introducing in Ocumare del Tuy: what is? Where it is?}

Ocumare del Tuy is a parish belongs to the municipality (Footnote 2) Tomás Lander, from the Miranda (Footnote 3) state; this is the administrative-policy division in the nation established in the Constitution of the Bolivarian Republic of Venezuela. The name of the municipality belongs to an important thinker like Tomás Lander (1792-1845), who's contributed with his liberal thoughts to promote the political changes in the process of the Venezuela independent. In the first instance this article definite the notions of people, according to Sartori [1] people translate form Italian is popolo, in French people and German volgue, is a singular noun. In English people is plural for this reason Sartori define (1994, 13-14) "...it is not fortuitous that's "people"(pueblo) (Footnote 4), in singular, lend itself to be understood as an organic whole, like a general and indivisible will, meanwhile the people look a discretional multiplicity, to your aggregate each". For this reasons people (pueblo) like concept got 6 definitions:

a. as literally everyone,

b. the major in number (the most),

c. as populace (lower classes proletarians),

d. as an organic whole and indivisible,

e. as the principle of absolute majority and

In this article people is definite as a result of the interaction between the populations of a geographical zone. This got the follow characteristics: presence of traditions dating back to the
pre-Columbian period, little dense geographical space, social relationships determinate as mentioned above, and that they are in constant cultural negotiation with manifestations coming from the big cities near like: San Antonio de los Altos, Los Teques and mainly Caracas. Thus, to refer the culture in Ocumare del Tuy is complicate because being a little municipally of the Miranda state (Footnote 6), its importance lies in the confluence of a centric cultural relations that reaffirm its regionalist or regional identity. The same is the heritage of Caribbean indigenous, his relationship with the Spanish conquer and the subsequent incorporation of the Africans slaves to the process of miscegenation, causing the emergency of a new sociocultural scenario, complexes with the advent of modernity. This article is a first approach to the elements and aspects of the Ocumare del Tuy culture, in order to avoid generalizations and determinisms, which in turn lead to concealments of historical specificities, cultural and social.

\section{Etymology and Something Else}

The name of Ocumare del Tuy it is of indigenous origin and is called ocum for a tubercle that grew up near the Tuy river, nowadays is known like ocumo (Footnote 7). Even though Gornés MacPherson holds that word Ocumare came from Cumarí, a kind of plant used by the Tacariguas Indians to knit their hamacas (Footnote 8) [2]. Also, Tuy is the name of the river that crosses many municipalities of the Miranda state, used for the Quiriquires Indians who lived on the banks of the river (Footnote 9). Apparently the Cumanagotos called Tucuy the water from the yuca (Footnote 10), and the contraction of the word, -fact facilitated by the Spaniard conquers-, to Ocumare added the word Tuy. In Barquisimeto 
city belongs to the Lara (Footnote 11) state the Caquetíos Indians use the word Tucuy, name of a little dove, used to call the Tocuyo (Footnote 12) river, Rojas [3].

According to Arístides Rojas the word Tuy it is of Castilian origin, specifically from the city of the providence of Pontevedra in Spain and it was granted to the river for its similarity to the indigenous word [3]. The influence of the indigenous heritage in this population is remarkable, like in the other municipalities of the Miranda state, evidenced in the names with which their respective foundations began (Footnote 13), combination between culture, Spanish catholic religion and elements of the indigenous culture. According to Mosonyi [4] this expresses that the foundation and main meaning of several regions of Venezuela is based on the indigenous component, because they were the first to identify their territory or societies (this reinforced their identity by assigning names to their living spaces), aspect that could not ignore the Spaniard.

In the specific case of Ocumare, in 1597 when it was founded, but it received the name of San Diego de Alcalá de Ocumare del Tuy in 1693. However, this town was well known like Valle de Súcuta de la Sabana de Ocumare, on this place there were farms with slaves and within walking distance there were churches. The churches were important at that time because they support cultural and political the domain of Spain in their colonies, in words of the bishop of Caracas Don Juan de Nicolás de Ponte:

Yltmo. Señor.= Don Juan de Nicolás de Ponte y los demás que aquí firmamos, parecemos ante V.S.Y.y decimos que por cuanto desde el Valle de Súcuta adonde tenemos ñras haciendas y esclavos de su beneficio, ay de distancia a las Iglesias más próximas, que son las de los valles del tuy arriba y charallave, cinco leguas de caminos sujetos a ríos y sus crecientes (...) Esclavos y familia, se ha de servir V.S.Y. de conceder su licencia para que en el Valle de Súcuta de la Sabana de Ocumare, q' es la medianía de las haciendas que tenemos en dho. Valle, labremos una Ygla. A que nos obligamos desde luego y a adornarla desentemente y pone en ella los ornamentos necesarios para la celebración en cada año... Don Juan de Nicolás de Ponte, 1693 [2] (Footnote 14).

The text is a solicitude to build a church in el Valle de Súcuta, it cannot be translated in English because it is old Spanish. The foundation of Ocumare del Tuy is the result of the petitions of its settlers, is a remarkable fact because unlike most of the cases where the foundations were the product of settlement of settlers. In fact, the meanings assigned to the settle are a form of relationship with the space. For the XVII century, this town is defining like people (pueblo), with a quiet life, where the main economic activities were the agriculture and grazing. Even three centuries after in 1953 still maintain the same characteristics:

What about this modest and laborious people? (...) of ordinary life, of homemade and familiar evolution, too individual and simple. It has the smell of its bahareque (Footnote 15) houses and is surrounded by the complacent freshness of the old trees. Farmer and merchant people (pueblo) with little tendency for the ideal things of the spirit [2].

In the Dictionary of the Royal Spanish Academy (DRSA) is found a definition of people related with the definition of Narciso Rodríguez, specifically the concept of "common people or humble" belongs to a town or village of "lesser category". The first define the social-economical activities exercised by the ocumareños, and the second is the distance experienced by the persons of that locality with respect to the benefits of illustration and science; stage of imminent progress for humanity. In these way the modernity not only means a new form of social organization even the instauration of new ways of life [5], which impact deeply in the generations of concepts of the reality, distinguishing itself from those not linked to its characterizing parameters, producing at the same time the identification and brand distinction (Footnote 16) of regions or social groups based on such process.

\section{The Ocumare del Tuy Foundation: A Cruel Event}

The access of the Spaniard conquerors to the Sabana de Ocumare it wasn't easy because a group of indigenous basically Teques, Mariches and Quiriquires attack the invaders. However, under the leadership of the lieutenant governor Francisco Calderón, in company of six hundred (600) of Indians guide for the Mariches Cacique (Footnote 17) Aricabuto defeated the indigenous resistance. The conquerors entered for Salamanca, a place between Charallave and Ocumare del Tuy [3]. From the geographical point of view Sabana de Ocumare (Ocumare del Tuy) were known for its riches of natural resources like flora and fauna diversities, surrounded for five (5) rivers (Lagartijo (Footnote 18), Súcuta, Marare, Aragüita and Ocumarito) that made communication possible. Such conditions allowed the settlement by the Spaniards commanded by lieutenant Calderón.

In 1577 the Quiriquires Indians attacked to Francisco Infante and Garci-Gonzalez in the Carayaca, both assigned commend to Ocumare del Tuy. Such action generated the pursuit, punish and death of the indigenous groups of the region not only for the Spaniards even the members of the tribe of Teques participate in this action [3]. The pacification of the territory was seen as something distant, not only for the confrontation Spanish Indian, even for the confrontation Indian Indian. Seventy-nine (79) years later of the conquest of Venezuela for Spain, it achieves the "peacefully" of Ocumare del Tuy.

\section{Ocumare del Tuy and its Cultural Heritage}

The town of Ocumare del Tuy doesn't have enough spaces and architectonical oeuvres, but the ocumareños give historical and symbolic value to the few that they have. One of them is the parish church; the structure was building with Etruscan influences:

... wide atrium, the main facade with a series of columns on relief of Romanian kind; on this rests the ledge with the classic triangular fronton, moldings on the tympanum and the apex of the two rampant cornices, there is San Rafael Archangel, with his trumpet 
...appears with the upright position of your biblical instrument, showing the souls: the supreme elevation that must reign in the hearts of men, or the ideality of saturated heights of infinity.

The subjective description presented by Narciso Rodríguez is notorious, which demonstrates not only the historical impact that the church has for the habitants of Ocumare del Tuy but also the importance it has at the level of the meanings: religious and material magic combination (Footnote 19). Other important space of the ocumareños is the Miranda school, which by 1935 was named Miranda Federal School, in which cultural and pedagogical events were organized. In 1938, it decided to transform it into a high school. By 1943 the Aveledo institute had been established, which year later was decreed as Pérez Bonalde (Footnote 20) high school, name that still has until today. In 1998 it is placed in the Simón Bolívar square of Ocumare del Tuy, a commemorative plaque in honor of the construction of the square that dates from 1930. This attempts to deepen the national ideology from local or regional identity.

In Venezuela there is a historical tendency to bring together cultural differences in the discourse of "national identity", this prior to the emergence of the globalization as a multidimensional process $[5,6]$. The national identity was constituted then - conceptually but not in fact-by elements of traditional order and of historical importance, for that reason it is a constant reference to the Independence deed, using the mains actors like: Simón Bolívar, Antonio José de Sucre, Francisco de Miranda among others, that is why it is not surprising the commemoration and recognition of these characters in the most recognized places in the country. This allows the communication and encounter between the diversity, fact possibilities for the state policy to reinforce the national identity notion (Footnote 21).

The recognizing of the people (pueblo) in the symbolic and material field has the objective the identity definition that allows to reduce uncertainty about the immediate environment, and turn identify the "Others" in this process, discovering central and peripheral tendencies, which finally give meaning to the whole. In fact, Villoro postulates a particular culture not only understands the current consensual values (positive moral), but also the projection of disruptive values declares current moral (critical moral), and therefore the intercultural dialogue implies the recognition of the values of each culture, but also of cross-cultural values, that is, recognized and carried out in different cultures. Blase [7]. Another symbolic component of the culture of Ocumare del Tuy is the coat of arm of the municipally Tomas Lander. It was designed for Manuel Aponte; it is containing the components of the socio historical and cultural heritage:

...it has division of three chains that are deployed from the three ends towards the middle of it, where there is a Phrygian cap (...) in the upper (blue color) it can see the beautiful valley tuyero lit by the sun, in the right bottom (red color) it is a group of weapons surrounded by the national flag and bay leaves putting over the church of San Diego de Alcalá; (...) in the left bottom (yel- low color) there is a pen with a inkwell and musical score, which represents the most excellent Lino Gallardo (Footnote 22) (...). In the upper of the coat of arm there is an inscription that shows the date « 5 de diciembre de $1597 »$ which is intertwined at each end with a plant of cumarí and ocumo roots(...), at the bottom there are heraldic blazons like those of the viscount of San Bernardo and the marquisate del Toro in which it reflected; « 11 de febrero de 1814» (date of the massacre of Ocumare) and «27 de abril de 1904» (date when Ocumare was the capital of Miranda state). (https://historiadelosvallesdeltuy.jimdo.com)

There is also another set of spaces and elements of historical and archeological order that have not been sufficiently studied and that configure the environment of ocumareño, such as: the Rangel Ruins, the Farmhouse del Toro in San Bernardo, the deposits of Cúcuta, the petroglyphs of democracy, Marare and Mararito, and finally the anthem of the municipality of Tomás Lander.

\section{Ocumare del Tuy and its Legends}

The habitants of Ocumare del Tuy experience in everyday life the fusion work-reason-myth-emotion, as Morin refers, in relation to loops that constitute the complex thinking. Sample of it, are the stories about Mauricio, a supernatural character who lived in a cave on the blue hill (cerro Azul). He is the caretaker of nature; he walks the paths to protect it and impart justice. It said that Mauricio found, a day that nobody remembers by means, his mission through a powerful enchant that lives in the bottom of a lake call horse tail (Cola de Caballo), one of those who form the Marare river current, who in the form of a beautifully woman took him to her mysterious kingdom and there the whole of his mission and returned him to the world of the living endowed with his extraordinary powers [8]. Currently this legend is known "the Mauricio cave", place of tourist and cultural attraction. Where the people are invaded by the ecstasy involved in the exceptional experience, momentary divorce with reality. Preeminence of the magical-religious experience, attending the Promethean handicap, a certain tendency towards Duvignon concepts.

\section{The Ocumare Traditions}

There are two cultural traditions in Ocumare del Tuy: San Juan Parrandero and Pilgrimage and escort of the Coromotanos Indians. The first is a reinterpretation of the Spanish Catholic religion, incorporating cultural elements of Venezuelan and more specifically Ocumare del Tuy.

In this regard Jesús García exposes the following: The San Juan Bautista brought by the Spaniards who imposed the Catholic religion with whip and cross, was reinterpreted and created by blacks, in our Mirandinas lands where different aspects of indigenous, European and African life and culture converged. García [9]. Although there are tendencies to generalize this tradition to the entire Miranda state, it is necessary to highlight that Ocumare del Tuy it arises from a differentiated event to other areas of the region. It dates back to June 24,1749 , date in which the blacks of Sabana de Ocumare rebelled against their masters, coinciding with 
the celebration of the patron saint San Juan Bautista. It is from 1915 that this date begins to be celebrated and when the celebration began "no trade opened in Ocumare del Tuy, the first bell was made in the church and from there the priest took San Juan to give it to the people of the town to celebrate with him..." [9]. Also, they walk to San Juan from house to house, considering people who had made a promise or will be called Juan, there the companions and owners of the selected houses dance, drink alcohol and eat.

In relation to the pilgrimage and escort of Coromotanos Indians of Ocumare del Tuy, it is a recent practice, on March 11, 1941 the first pilgrimage was made in honor of the patroness of Venezuela, the Coromoto virgin (Footnote 23). In this sense, tradition has nothing to do with events of centuries of year of existence, since there are traditions created before the emergence of modernity but also after it [10]. What defines a tradition is particularly the repetition and emotional burden that it means for those who experience it.

At the forefront of this nascent tradition was the priest Rafael Pérez León and then impetuous Young man of fifteen years old Jesús Tereso Sánchez, whom they named as Cacique of that pilgrimage that was just beginning (...) Accompanying the Cacique on that occasion and the years to come, a large number of faithful (promeseros) dressed as aboriginal, some on foot and others on horseback, some mounted on floats, a number equally faithful (promeseros) dressed as angels (..) The procession ends in front of the church where the national anthem (of Venezuela) is sung and the Coromoto virgin is accompanied to her place inside the church. (Marcano, $\mathrm{n} / \mathrm{d}$ ). It is faced with the presence of cultural fragments that give meaning to tradition, which is conceived for a coherent signature by the people of Ocumare, without questioning the hybrid or miscegenation experience in which they find themselves. That is cultural practices define the environment and are not perceived as problematic or conflicting, they are assumed because they have been significantly rebuilt. Evidencing at the same time the miscegenation of global and local flows as Alicia Silva [11] puts it; however, she points out that the local phenomena must be analyzed from their particularities because that allows their location on the world stage [12-17].

\section{Conclusion}

The cultura in Ocumare del Tuy it is interesting because it poses research challenges from various disciplines. At the moment it is difficult to understand the dynamic of a certain space but it involves trends: social, historical, political, cultural, archeological, economic among others. All of them produce meanings that give sense and contextualize contemporary environments. Understand the culture in Ocumare del Tuy implies considerate the vestiges of the past to blend in with its historical and social specificity. Ocumare del Tuy is not a "island" inside Venezuela, since it is connected through common identity elements, but differences are evidenced in an important way with respect to the nation as a whole, and it is there where the importance of its studies resides.

\section{References}

1. Sartori Giovanni (1994) ¿Qué es la democracia?. Editorial Altamira, Colombia, USA.

2. Rodríguez N (2008) Retazos: Microbiografía de Ocumare del Tuy. Colección Bibliografica General, Venezuela.

3. Flores J (2012) Historia sobre la fundación de Ocumare del Tuy. Recuperado de, Germany.

4. Mosonyi E (2013) Identidad nacional y culturas populares. La Enseñanza Viva, Venezuela.

5. Giddens A (1990) Consecuencias de la Modernidad. Alianza Editorial, España, Spain.

6. Brünner J (1998) Globalización cultural y posmodernidad. Fondo de Cultura Económica, Chile.

7. Gonzalez (2011) Estigma. La identidad deteriorada. Amorrortu, Argentina.

8. Sánchez J (1995) Mauricio el encanto de Ocumare. Revista Matria.

9. Lozada J (2012) Dossier 2.2: San Juan Bautista: el parrandero de Ocumare del Tuy. Revista Matria. Argentina.

10. Giddens A (1999) Un mundo desbocado. Taurus, Argentina.

11. Silva A (2005) La globalización cultural y el reto de las tecnologías de información y comunicación en la sociedad - red. Globalización y multiculturalismo. DCH - Universidad de Carabobo, Venezuela.

12. Gobernación del Estado Miranda (2012) Tradiciones del estado Miranda. Editorial Arte, Venezuela.

13. Goffman E (2008) Estigma. La identidad deteriorada. Amorrortu, Argentina.

14. Flores B (2013) Peregrinación y escolta de los indios coromotanos de Ocumare del Tuy. Recuperado de

15. Fuentes C (2005) El espejo enterrado. Taurus, Argentina.

16. Municipio Tomás Lander - Ocumare del Tuy. (https:// historiadelosvallesdeltuy.jimdo.com)

17. Oropeza A (2005) Política pública y demanda cultural en Venezuela. Cendes-UCVm, Venezuela. 
This work is licensed under Creative Commons Attribution 4.0 License DOI: 10.19080/GJAA.2019.10.555793

\section{Your next submission with Juniper Publishers will reach you the below assets}

- Quality Editorial service

- Swift Peer Review

- Reprints availability

- E-prints Service

- Manuscript Podcast for convenient understanding

- Global attainment for your research

- Manuscript accessibility in different formats ( Pdf, E-pub, Full Text, Audio)

- Unceasing customer service

Track the below URL for one-step submission https://juniperpublishers.com/online-submission.php 